\title{
The Importance of Financial Performance for Evaluating Supplier Performance - a Comparison with the Internal Ratings of Credit Institutions
}

\author{
Gunther Meeh-Bunse \\ University of Applied Science Osnabrueck, Germany \\ Anke Hermeling \\ University of Applied Science Osnabrueck, Germany
}

\begin{abstract}
Due to changing procurement policies and procurement markets, suppliers increasingly face evaluation of their holistic supplier performance. In this context, the assessment of financial strength is increasingly emphasized. Hence, (potential) suppliers are required to prove their financial soundness towards the assessing (potential) corporate customer. Traditionally, such evidence was only to be offered to banks that create compulsory internal credit ratings. The goal of this paper is to compare procurement in voluntary supplier performance evaluation, particularly the assessment of financial strength, with the procurement when creating compulsory internal ratings by banks. This should on the one hand identify potential concordances and interdependences while on the other hand improve awareness for suppliers. Presentation and analysisof selected indicator systems assess financial strength within supplier evaluation and within the internal rating by banks. Despite the potential different objectives of banks and (potential) corporate customers apparently significant trends of financial (dis)soundness can be recognized as part of the supplier evaluation as well as part of the internal ratings by banks. It follows that hypothesis can be identified which in future work can be empirically tested. The result also provides a start to initiate further research e.g. about a possible (partial) externalization of already existing internal rating data by credit institutions. This then could be used in the context of supplier evaluation reducing overall cost.
\end{abstract}

Keywords: access to finance, SMEs, supplier evaluation, quality, market JEL classification: G00, G21, G18

\section{Introduction}

The processes of change in procurement markets (Kraljic, 1983, Ellram et al., 2014, Arnolds et al., 2012), connected to an increasing concentration among companies on their core competencies, have led to a reduction in companies' vertical range of manufacture and have consequently increased their procurement depths (Ellram, 1990,Ellram 1995). These developments mean that procurement has significantly increased in importance. Whereas the traditional procurement departments of the past only encompassed operational and dispositive activities in support of a company's production and sales capacity function, the procurement function is now understood as a strategic success factor, which exerts a considerable influence on operating income (De Boer et al., 2001). 


\section{Supplier Evaluation}

Due to the increasingly close integration of suppliers in the companies' production processes, it is natural to assign a central role to the identification, evaluation and selection of the "right" potential or already established suppliers (De Boer et al., 2001). Various scientific publications have reported that there are benefits to a systematic approach to supplier selection (such as Weber et al, 1991, Vonderembse et al., 1999). Suppliers are thus increasingly subject to a review of their holistic performance as suppliers (Hirakubo et al., 1998). The relevance of evaluating financial performance is increasingly emphasized in this context (Min, 1994, Simpson et al, 2002). Arnold et al. (2012) stated that solvent companies are better able to guarantee a timely and continuous supply of products of an assured quality, contingent on the necessary investments, product improvements and developments. In addition, financially sound suppliers with high profits are more likely to reduce their price than marginal sellers. Using the automotive supply companies "Peguform" and "Delphi" as examples, Schneck (2006) describes the potential danger of financially weak suppliers filing for bankruptcy. This would also threaten internal fulfilment of demand.

These findings have led to situations in which (potential) suppliers are increasingly being required to prove to the assessing company that they are financially sound. Traditionally, this has only been done in the context of internal ratings by banks or rating agencies.

\section{Internal Ratings by Banks}

Banks are typically assigned the economic task of transforming terms and credit risks. This task has made internal ratings in the credit business a core function of banks (Bieg et al. 2011). With the introduction of the Basel framework regarding equity recommendations for banks (Basel II; now replaced by Basel III), they were required to systematically assess their credit risks for the first time. According to the rules of the CRD IV package, the systematic evaluation of credit risks can be based on two different approaches: a credit risk standardized approach (SA) based on external ratings or an internal-ratings-based approach (IRBA). Banks that use the IRB approach determine the default risk at the level of individual loans and borrowers, and make their lending decisions based on this.

\section{Intersections between Supplier Evaluations and Internal Ratings by Banks}

The assessment of financial soundness as a feature of supplier performance and the internal ratings by banks are, among other things, generated on the basis of annual financial data. This qualitative analysis should make it possible to develop, based on previous business performance, forecasts or trend predictions for the future, or uncover relevant opportunities and potential risks. This quantitative information is complemented by qualitative criteria. The analysis of the qualitative evaluation criteria involves, among others things, assessing management quality, evaluating competitiveness, succession planning, etc. It seems almost impossible to objectively compare qualitative data. Therefore, in the authors' view, the focus of the evaluations is on the analysis of qualitative criteria. Depending on the direction of the evaluations, the financial statements are viewed from different perspectives in order to gain an impression of the liquidity, market success, cost structure and other factors and to describe them using company performance indicators. 
The authors begin from the fact that despite the determination of the evaluation results by their target function, it is possible to detect significant trends of financial (un)soundness, both in the context of supplier evaluations and the internal ratings of credit institutes. From this, the authors develop the hypothesis that the internal ratings by banks can make statements that are relevant for supplier evaluation. An analogous system for supplier evaluations of financial soundness to the internal ratings systems by banks should therefore be examined.

\section{Methodology}

To verify the hypothesis presented, the authors draw on example-oriented descriptions and the analysis of selected indicator systems to evaluate financial performance in the context of supplier evaluation and the internal ratings by banks. For this purpose the authors renounced a comprehensive quantitative evaluation, but rather adduced two representative examples forbothevaluation systems. The underlying examples of this paper were selectedon the basis of an appropriate literature review. It became clear that comprehensive supplierevaluation systemsoperational in companies are hardly published. In this context we default to asound example on the basis of our literature review. For the purpose of comparison with an internal rating system applied by banks, we refer to the internal rating system of the German Association of Savings Banks (Sparkassen Verband), as one of the market leaders in Germany.Both presented rating systems concernacompilation of established covenants. These covenants can be largely derived from the company's annual financial data. For reasons of clarity and comprehensibility we make use of four main comparison groupsin order toassign thecovenants.

Table 1

Comparison of the key indicator systems in the context of a supplier evaluation and the internal ratings using the example of the German Association of Savings Banks (Sparkassen Verband)

\begin{tabular}{|c|c|c|}
\hline & Supplier Evaluation & Internal Ratings by Banks \\
\hline \multirow[t]{11}{*}{ Key performance indicators } & Net income & Return on capital \\
\hline & Return on sales & Return on sales \\
\hline & Return on equity & Operating profitability \\
\hline & Return on assets & Cash flow rate \\
\hline & Operating profit (EBIT) & Gross profit rate \\
\hline & & Personnel expense ratio \\
\hline & & Depreciation rate \\
\hline & Rental expense ratio & Rental expense ratio \\
\hline & Interest expense ratio & Interest expense ratio \\
\hline & & Turnover per employee \\
\hline & & Per-capita income \\
\hline \multirow[t]{5}{*}{ Financing and liquidity ratios } & Cash flow & Asset coverage \\
\hline & Days payable outstanding & Short-term liquidity \\
\hline & Dyn. operating profit & Dyn. debt ratio \\
\hline & 3rd degree liquidity & Days sales outstanding \\
\hline & Capital commitment & $\begin{array}{l}\text { Days payable outstanding in days } \\
\text { Storage time in days }\end{array}$ \\
\hline \multirow[t]{3}{*}{ Balance sheet key figures } & Equity ratio & Equity ratio \\
\hline & Equity to fixed assets ratio & Short term debt \\
\hline & $\begin{array}{l}\text { Stock index number } \\
\text { Storage time }\end{array}$ & Capitalization ratio \\
\hline Other key figures & & $\begin{array}{l}\text { Total capital turnover } \\
\text { Investment rate } \\
\text { Depreciation on fixed assets } \\
\text { Self-financing ratio }\end{array}$ \\
\hline
\end{tabular}

Source: based on Disselkamp et al. (2004) and Gleißner et al. (2014) 


\section{Results}

A comparison of the criteria and performance indicator systems for assessing the financial performance of a company between supplier evaluation and the internal rating systems by banks hints at three issues in particular. First, it can be stated that analyzing annual financial statements, notwithstanding the criticism of their ex-post analysis, plays an important role for both methods. The annual financial statement analysis allows an objective assessment of a company's finances on a regular basis, since the information used mainly comes from the company's (audited) financial statements and the evaluation is usually done by machine. Thus, it should ordinarily be possible to reconstruct the results at any time.

Second, it could be shown that both methods of financial statement analysis depicted have a basic congruence. Both methods make use of proven indicator systems that involve an analysis of the income, financing, liquidity, and balance sheet ratios. The calculation of the respective ratios apparently largely occurs in an overlapping manner. Their results are evidently correlated.

Third, when comparing the evaluation procedures, it is important to always bear in mind that they are determined by their respective target functions. The determination of financial performance as a touchstone for evaluating supplier performance should provide information on the (potential) benefits and risks of a long-term customer-supplier relationship. Banks' internal rating procedures serve to systematically evaluate default risks to determine regulatory capital requirements and calculate internal risk costs. The diverging target functions of the evaluation process are likely reflected in the actual selection, weighting and scope of the indicators used. To make more specific statements in this regard, there is a need for further empirical research.These results confirm the initially formulated hypothesis.

\section{Discussion}

The deduced existence of intersections between the described methods for evaluating companies' financial performance prompts the question of whether a (partial) externalization of the information on internal ratings developed by banks could be valuable for evaluating companies when rating suppliers. As outlined above, comprehensive supplier evaluation systems operational in companies are little revealed. Future empirical research is deemed necessary on application of comprehensive supplier evaluation system. Following this, another alignment should ensue to test our hypothesis.

Moreover, it is open to discussion whether a (partial) externalization could provide added value for the companies being assessed, the suppliers. First, it is important to consider that the relevance and fundamental congruence of the evaluation processes presented here were merely based on the analysis of the financial statements. Qualitative criteria may have to be left out of consideration, because of the absence of established guidelines that make them measurable. A discussion of a possible externalization of internal ratings by banks can therefore only be suggested for sub-area of quantitative criteria. In consequence, additional questions are ignored in the context of this article.

Via a possible externalization of processed and condensed information from the analysis of financial statements by banks, one could, in the view of the authors, undoubtedly make statements about the basic financial soundness of the rated companies. With respect to the evaluating company, this would mean that it would not need to have a corresponding capacity to evaluate a supplier's financial performance within the company. This would particularly benefit SMEs, since they 
can hardly have adequate capacity available on a regular basis and are not in a position to create it. This resource-saving effect is likely to be directly measurable in monetary terms. At the same time, it is important to consider that the suppliers could also benefit from an externalization. One can imagine this taking the form of a certification function that makes transparent previously proven solidity and allows for more advanced forecasting on this basis. In the context of the supplier-customer relationship, this "certified" credit rating could also, for example, strengthen the negotiating position with suppliers and investors. In practice, there are already service providers offering information about the financial health of companies (suppliers), but the reliability of this information is not supported by industry regulation.

\section{Conclusion}

By showing the two indicator-based systems for evaluating financial performance in the context of supplier evaluation and bank ratings, intersections between the two systems could be identified. Despite the determination of the results by their target function, significant trends of financial (un)soundness can seemingly be identified. The results found here support the hypothesis that the internal ratings by banks can make statements relevant for supplier evaluation. A possible (partial) outsourcing of internal ratings by banks could, in the authors' view, create added value for the evaluating and the evaluated companies.

\section{References}

1. Arnolds, H., Heege, F., Röh, C., Tussing, W. (2012), "Materialwirtschaft und Einkauf", Springer Gabler, Wiesbaden.

2. Bieg, H., Krämer, G., Waschbusch, G. (2011), "Bankenaufsicht in Theorie und Praxis", Frankfurt School Verlag, Frankfurt.

3. De Boer, L., Labro, E., Morlacchi, P. (2001), "A Review of Methods supporting Supplier Selection", European Journal of Purchasing and Supply Management, Vol. 7, pp. 7589.

4. Disselkamp, M., Schüller, R. (2004), "Lieferantenrating", Gabler, Wiesbaden 2004.

5. Ellram, L. (1990), "The Supplier Selection Decision in Strategic Partnerships", International Journal of Purchasing and Materials Management,Vol. 26 No. 4, pp. 814.

6. Ellram, L., Cooper, M. (2014), "Supply Chain Management: It's All About the Journey, Not the Destination", Journal of Supply Chain Management, Vol. 50 No. 1, pp. 8-20.

7. Gleißner, W., Füser, K. (2014), "Praxishandbuch Rating und Finanzierung", Vahlen, München.

8. Hirakubo, N., Kublin, M. (1998), "The relative importance of supplier selection criteria: the case of electronic components procurement in Japan", International Journal of Purchasing and Materials Management, Vol. 34 No. 1, pp. 19-24.

9. Kraljic, P. (1983), "Purchasing must become Supply Management", Harvard Business Review, September-October, Vol. 61 No. 5, pp. 109-117.

10. Min, H. (1993), "International Supplier Selection: A Multi-Attribute Utility Approach", International Journal of Physical Distribution \& Logistics Management, Vol. 24 No. 5 , pp. 24-33.

11. Schneck, O. (2006), "Lieferantenrating in der Automobilindustrie" (Supplier Rating in the automotive industry), Kredit und Rating Praxis, Vol. 4, pp. 6-9.

12. Simpson, P., Siguaw, J., White, S. (2002), "Measuring the Performance of Suppliers: An Analysis of Evaluation Processes", The Journal of Supply Chain Management, Vol. 38 No. 4, pp. 29-41.

13. Weber, C., Current J., Benton, W. (1991), "Vendor Selection Criteria and Methods", European Journal of Operational Research, Vol. 50 No. 1, pp. 2-18. 
14. Vonderembse, M., Tracey, M. (1999), "The Impact of Supplier Selection Criteria and Supplier Involvement on Manufacturing Performance", The Journal of Supply Chain Management: a Global Review of Purchasing and Supply, Vol. 35 No. 4, pp. 33-39.

\section{About the authors}

Gunther Meeh-Bunse is a Full Professor at the Department of Management and Technic at the University of Applied Science Osnabrueck, Germany. Main Fields of expertise: Business Finance, IFRS, Rating and Financial Analysis. The author can be contacted at g.meeh-bunse@hs-osnabrueck.de.

Anke Hermeling is a Research Assistantat the Department of Management and Technic at the University of Applied Science Osnabrueck, Germany. Main Fields of expertise: Business Finance, Rating. The author can be contacted at a.hermeling@hs-osnabrueck.de. 